\title{
Is Diplomacy A Success Or Failure? A Study from the Perspective of Kashmir Issue
}

\author{
Farhana Owais \\ Ph.D Scholar \\ University of Karachi \\ Karachi \\ farhanaowais@ymail.com \\ $\&$ \\ Prof. Dr. Muhammad Ahmed Qadri \\ Former Dean, Faculty of Arts \& Social Sciences \\ University of Karachi \\ Karachi
}

\begin{abstract}
This research explores the success or failure of diplomacy on part of United Nations Organization and international community in case of Kashmir issue, the conflict area between Pakistan and India. By using qualitative research method, a brief historical background of Kashmir issue and role of the United Nation has been explored. Pakistan contemplates Kashmir as its key political dispute but India did not accept it. The decision of Kashmir issue was reviewed by UN Security Council on $21^{\text {st }}$ April 1948 according to its $47^{\text {th }}$ resolution. The Security Council sent a commission to sub-continent in 1948 to solve the issue by impartial plebiscite in Kashmir. India and Pakistan did not accept this commission but they appreciated the mediation done by UN commission. After considerable efforts the commission declared its failure in December 1949. The United Nation has power to ensure peace in Kashmir and had plebiscite. While talking about plebiscite it is according to UN resolution of January 1949 which laid down. "The question of the accession of the state of
\end{abstract}


Jammu and Kashmir to India or Pakistan will be decided through impartial plebiscite under UNO" (Ministry of Foreign Affairs, 1949, January 10).

KEYWORDS: Diplomacy, Kashmir Issue, International Community, United nation organization, Musharraf solution, Plebiscite.

\section{INTRODUCTION}

Diplomacy is the management of international relations among states with the help of diplomats, ambassador's or other civilian groups. It is an integral part of diplomatic activities of almost all countries in our days. Sometimes there could be many complications between the states when they could not communicate and try to influence each other to get a solution. The best way to communicate and solve the problem is through diplomacy because wars have never been a solution to any conflict. This research explores the role of diplomacy on part of United Nations Organization in case of Kashmir issue, the conflict area between Pakistan and India. The dispute over Kashmir is as old as the partition of Indian sub-continent. The denial of settlement on Kashmir issue by the Indian government is due to the reason of the claim that state of Kashmir is legal part of India. The united nation is a strong organization to maintain peace in the world and to settle down conflicts among countries. The general assembly and Security Council are two main responsible organizations working on settling down disputes around the world. Now its UN responsibility to exercise its power and ensure peace in Kashmir and have plebiscite. It can arrange talks between the two countries facing problems. It can support both countries resolving the conflicts and saving the people of Kashmir. By using qualitative research method, the article explores a brief historical background of Kashmir issue and role of United Nation organization and international community in the resolution of Kashmir issue.

\section{RESEARCH PROBLEM}

1. Is Diplomacy A Success Or Failure? A Study from the Perspective of Kashmir Issue. 


\section{BACKGROUND OF THE STUDY}

\subsection{What Is Diplomacy?}

Diplomacy is the management of International relations among States with the help of diplomats, ambassador's or other civilian groups (Kissinger, 2012, 114-115). Diplomacy may be made by the heads of States by foreign ministers and sometime by specially assigned government officials. Sometime by specially designed persons who are specialist in their professions like teachers, businessmen and artists etc. Diplomacy is sometimes formal while negotiating problems with full Knowledge of the world and sometimes it is secret without knowledge of any other country (Watson, 2013, 1). However, a traditional diplomacy is a process of maintaining relations between and among states it is a system for friends to co-operate and for enemies to settle down disputes without the use of force (Barston, 2014, 1).

\subsection{Complications in Diplomacy}

There could be many complications between the States some times when they could not communicate properly and try to influence each other to get a solution done which becomes more dangerous, the best way is to communicate properly and if required bargain and adjust differences through diplomacy. Although a wide range of methods are used for conflict resolution, it may be negotiations, mediation, arbitration and diplomacy, and whichever is the best way to settle disputes. The prominent quality of the ambassador or diplomat is his communication ability. (Faizullaey, 2006, 491-522).

A positive conversation and ability to listen to the counterpart is extremely important, because a diplomat must have this quality to convey the message or issue of his government or State to the other country through his counterpart. It is diplomat who builds the reputation of his country at international level. 


\subsection{Diplomatic Way To Adjudicate}

Wars have never been a solution to any conflict. Diplomacy is the only way to adjudicate disputes and conflicts. We can include different example to explain.

- The former UN secretary general Mr Kofi Anan was nominated as a joint special envoy of UN and the League of Arab to end the Syrian crisis. This was done just to bring the conflict to an end (Hinnebusch \& Zartman, 2016, 1).

- European Union External Action Service (EEAS) established in 2009, the purpose of this service was to stop the disputes and building of the peace process (Vanhoonacker, \& Pomorska, 2013, 1316-1331).

- The efforts of the American President, Bill Clinton who tried to bring Israeli and Palestinian leaders to an agreement over the issue of dividing the states. (Soetendorp, 2002, 283-295).

- In 1986, a meeting was held in Iceland between American President Reagan and Russian president Gorbachev regarding banning of all ballistic missiles but Mr Reagan wanted to continue research program. So, this meeting ended on arms control and it was decided for both sides to reduce Nuclear Arms (Jackson, 1998, 617-619).

- Former American President Mr. Carter arranged a meeting between Egyptian President Mr. Sadat and Israeli Prime minister in 1970 to maintain peace on both sides; this is called Camp David peace Accord (Telhami, 1990, 1).

- Negotiations held between President Nixon and Leonid Brezhneve at United States and Soviet summit 1970 regarding Arms Control (Nixon, 1998, 199-219).

- Under Secretary of state Mr Richard Armitage worked very hard to defuse dangerous situation between India and Pakistan in 2001. (Kapur, 2008, 71-94). 
- After Arab-Israel war in 1973, former U.S Secretary of State Henry Kissinger tried to resolve tensions in the Middle East through shuttle diplomacy (Gazit, 2013, 1).

- Former American assistant secretary of state Christopher hill held talks with North Korea regarding its nuclear program in 2006-2007 (Niksch, 2010, 1).

\subsection{Tony Blair's 10 Principle To Guide Diplomats}

The British mediator and former prime minister Tony Blair offered 10 principles to advise the diplomats how to resolve the conflicts through the example of northern island peace issue process, he suggested ways to solve the disputes.

The conflict was about Northern Ireland Protestant Bruisers who wanted to keep north part of the UK and Catholic Irish who wanted the North to unite with Ireland. While working on this issue, Tony Blair said there are 10 principles, which can be applied, on any conflict for resolution. (Blair, 2010, 699).

These are given as follows:

1. Agree on a common framework

2. Grip the Conflict relentlessly

3. Attend to minor matters

4. Be creative

5. Rely on third parties

6. View resolution as a journey

7. Prepare for disruption

8. Capitalize on Leadership

9. Seize on external change

10. Never give up 
After nine years of effort people from both sides agreed to work together to resolve the issue. This was an incredible accomplishment. We can say it is a model case for those who feel trapped in an unsolvable conflict.

\section{IS DIPLOMACY A FAILURE?}

\subsection{Conflicts and Challenges}

Conflicts are either within the country or between the two countries are menaces to international Peace. When conflicts violate international Laws, they cause problems. There are some cases, which look like a failure of Diplomacy like conflicts between Israel and Palestine, War in Syria, conflicts in Somalia, tension between Pakistan and India regarding Kashmir etc. Challenges are very high in $21^{\text {st }}$ century regarding diplomacy, which needs to be addressed. There are some more examples where we see diplomacy as a failure, like delayed international military response to genocide in Rwanda, ethnic cleansing in Bosnia and in Myanmar. Similarly, economic Sanctions against South Africa and Yugoslavia (Viotti, \& Kauppi, 2013, 207).

Generally, it is said that there have been three methods in common to resolve conflicts among nation states since long i.e.

- Diplomatic way.

- Military way.

- Economic way.

The traditional diplomatic strategies were applied after the cold war. States always care about their benefits and they want to come to a solution point of mutual interest by using trade diplomacy i.e. by giving and taking techniques. Although States need to strengthen their regions by avoiding armed forces for conflict settlement. Military is used for peacekeeping purposes, for relief and helping people. 


\subsection{The Role Of United Nation In Settling Down Conflicts}

\subsubsection{UNITED NATION}

UN has responsibility to adjudicate the international disputes in a peaceful manner among countries. The main object of United Nation is to maintain peace with the help of international law. This has been stated in article 1 of UN charter (Schrijver, N.J, 2006, p. 34).

In this regard, General Assembly and Security Council are organizations with high responsibilities. General Assembly has the power to maintain peace and to settle down the issues while Security Council has the power to deal with threats which create problems to maintain peace and security. The Security Council has power to call both parties to settle down the problems among them. According to the article 41-47 of the charter Security Council has the right to take decision (Harpher, K, 1994, p. 103).

Security Council has been very helpful in resolving colonial issues for getting independence and establishing possible government. On the other hand in other cases it has not solved the underlying issues but just close them. Clashes in most of the scenarios has been decreased but not entirely managed. In case of Kashmir, Middle East, Cyprus and Swiss disputes the record of United Nation is not as satisfactory as it has been anticipated.

\section{THE ROLE OF UNITED NATION OVER THE CLASH OF KASHMIR}

\subsection{Clash Of Kashmir}

The dispute over Kashmir between Pakistan and India is considered among the most extensive and persisting dispute in the world. The truth is that Kashmir issue is still unresolved. The question now is what United Nation is doing as an international organization to solve this problem. The responsibility of the United Nations is to solve this issue and maintain peace in the region. Although the UN has passed numerous resolutions regarding this issue since 1947 but the problem remains still unresolved This article examines the role and confrontation faced by 
United Nation in this issue and also explains the historic background of this issue. The denial of settlement on Kashmir issue by the Indian government is due to the reason of claim that Jammu and Kashmir is their internal matter. According to Indian government an agreement was signed by Maharaja Hari Singh (the ruler of Kashmir in 1947) and the governor general of India on $25^{\text {th }}$ October 1947. Due to this agreement India claimed Kashmir as its legal part.

\subsection{Wars Over Kashmir}

Pakistan and India had 3 wars over the State of Kashmir. The first war was fought just after a few weeks of the independence (1947-48). During the first war Maharaja Hari Singh asked India for help against Pakistan. India offered its help but with subject to signing an agreement for becoming a part of India. After the succession of Kashmir to India on 26th October 1947 the Indian military forces entered into Srinagar. Although the outcomes of the dispute was not decided but the conflict came to an end by the intervention of United Nation.

\subsection{Second War Over Kashmir In 1965}

Kashmir has always been a Muslim majority state. Initially its ruler was Hindu and the Pakistan's government continued to believe that the majority Muslim state should belong to Pakistan, because it was decided at the time of partition that Muslim majority areas will be considered part of Pakistan. In 1965, Pakistani and Indian forces fought over Kashmir territory along the border.

When Pakistan assail Kashmir, India requested the United Nations to play its role in ending the war. On 20th September 1965 Resolution 211 was passed by Security Council calling for an end to war. The United Kingdom and United States supported the decision of UN and soon cut off the supply of arms and ammunition. Pakistan and India accepted the Ceasefire on $21^{\text {st }}$ September 1965. (Mohan, A, 1992, p. 283-308).

After Cease-fire the Soviet Union played its role as a third party negotiator and brought both parties to the negotiating table in Tashkent, 
which ended in January 1966, In spite of these wars both countries could not find any positive solution of this dispute ("Kashmir - The Kashmir problem,").

The United Nations Commission for India and Pakistan (UNCIP) developed an observer group to monitor the line of control, which is about 400 miles in Length between the two countries and they continued their observation until the third war broke out in the year 1971. (Cohen, 2004).

\subsection{Efforts Made by Media Group Through Cultural Diplomacy}

Pakistan has always struggled to maintain better relations among its neighbors, especially with India. There have always been issues among the two countries but Pakistan has always made an effort to sustain it through diplomacy. A leading Pakistani media group Jang initiated a campaign not only to resolve this issue but to maintain peace between two nations under the umbrella of cultural diplomacy.

\subsubsection{CULTURAL DIPLOMACY BETWEEN JANG AND TIMES OF INDIA GROUP}

When diplomacy is used to build good relations among countries for supporting the policies of each other on the basis of exchanging cultural heritage is called cultural diplomacy. The aim of cultural diplomacy is to promote good relations among countries and to plan better strategies. There are lots of similarities between Pakistan and India regarding their language and food, despite of the difference in their religion that is Hindu and Muslim. Two leading media groups of India and Pakistan jointly initiated the campaign named Aman-Ki-Asha for the promotion of peace and cultural relations. Aman-Ki-Asha was launched on $1^{\text {st }}$ Jan 2010 by the Jang group of Pakistan and times of India group. A poem was written by the Indian poet Gulzaar and sung by renowned Pakistani Rahat Fateh Ali Khan. Indian film superstar Amitabh Bachan recited it. Many productive programs were done under this umbrella of Aman Ki Asha. These two groups promoted love and peace. This was a good effort because in history no media houses did such a marvelous job to maintain peace. This peace initiative made positive changes in Indian minds about Pakistan. This peace project was designed for the betterment and economic uplift of the 
common people of both countries. Survey conducted in India after one year of Aman-Ki-Asha revealed positive outcomes. The relation between people of both sides became better and stronger.

\subsubsection{PROGRAMMES ARRANGED BY AMAN KI ASHA}

1. Literary festival across India.

2. A music festival in several cities of India

3. Indo-Pak mushaira in Karachi

4. Senior editors and anchors conference in Karachi

5. Strategic seminar in Lahore on the topic of a common destiny

6. Trade and investment conference in new Delhi

7. Peace hankies chain, thousands of school children from both countries signed hankies.

8. Created awareness on the issues of

- Kashmir dispute

- water dispute

- terrorism

- visa difficulties

- prisoners' woes

- economic collaboration

These were the efforts made by Pakistani media group to improve the relation with the neighboring country.

Pakistan took initiatives many times to solve this issue even appreciated international Community to resolve this as a negotiator. But India has only one claim that it is their internal matter. This matter needs a continuous engagement of the United Nations towards a permanent solution. Pakistan has always tried the best to build good relations with India even by using cultural diplomacy, many programs were initiated to maintain good ties like managing various cultural programs through writers, artists and sportsmen; but India did not take it equally.

It is a fact that there have been some weaknesses from the government side because of the lack of confidence between governments, army and Judiciary. Another reason is the frequent change of administration, because every time when the administration changes the policies also get 
changed. Every government has its own priorities. Except military Leaders who took measures to solve this issue. Military Leader Gen Pervez Musharraf took it very seriously and tried to maintain better conditions of Kashmiris and provided protection to them from the killings under Indian military command.

Because of political instability, Pakistan could not project this issue internationally in a strong way and because of a continuous change of administration, the country could not maintain its foreign relations properly. In Nawaz Sharif tenure there was no foreign minister, which created a big gap between Pakistan and other countries of the world. This continuous change also weakened the economy of Pakistan. Because of these conditions UN could not talk to Pakistan regarding this issue.

The present Pakistani government under the Prime minister ship of Imran Khan is working very hard to resolve this issue, after reviewing all diplomatic, legal and political aspects of Kashmir Prime Minister have decided to take this case to the International court of Justice.

The United Nation Security Council resolution 47 adopted on $21^{\text {st }}$ April 1948 concerns the resolution of the Kashmir conflict. In September 2019 when $74^{\text {th }}$ session of the general assembly was held in New York, Pakistani prime minister Imran Khan expressed his deep concern over the use of Indian security forces to subdue the people of Kashmir, which is continuous human rights violation and he condemned this act very strongly.

American president Donald Trump also offered to mediate on Kashmir, which Indian Government rejected. Pakistan took this issue to organization of Islamic Conference against the crackdown in Kashmir.

\subsection{Importance Of Kashmir}

Kashmir is rich in resources, which includes tourism, agriculture, handicrafts, and most important water resources. Because Kashmir is 
surrounded by glacier peaks, River Jhelum, Chenab, Indus and Tawi are flowing through this state. Kashmir Valley is famous for its lakes and beautiful gardens.

We can say a strong reason of clash over Kashmir is water. Indus river basin Starts from Kashmir. Its branches move towards Pakistan $60 \%$ and towards India $20 \%$ towards Afghanistan 5\% and about $15 \%$ in China. (Schofield, V, 2010, p. 1).

The Indus water treaty was signed between both countries in 1960 according to this treaty water right of 3 eastern rivers were given to India those are Ravi, Sutlej and Beas whereas 3 western rivers' rights were given to Pakistan those are Jhelum, Indus and Chenab. India has started violating against the Indus Basin treaty. (Biswas, A.K, 1992, p. 201-209).

\subsection{Role of Kashmiri People}

For decades Kashmiris are deprived from their due rights. Young Kashmiris are struggling for their rights against Indian military forces. These youngsters are trying to realize the world about the problems they are facing to get freedom and they also realize that their Leadership has no power to present their case at Global platform - Indian Politicians are playing with their leaders and most of them have been house arrested. 26 different political, social and religious Kashmiri organizations formed one party altogether: that is Tehreek-e-Huriyat on 9th March 1993.

This alliance was made to raise the cause of Kashmir. This party is led by Mir Waiz Umar Farooq and Syed Ali Shah Gilani Yasin Malik who is another Kashmiri Leader. They believe that the Kashmir issue is not being presented to UN properly and if other countries will not help to resolve this conflict then it may lead the youngsters towards terrorism to get their right of self-determination.

\subsection{The Role of International Community}

The US is a permanent member of UN Security Council who has the right like other four members to execute India forcefully because India is 
not willing to resolve this position peacefully. The US and India have strong economic ties and the United States do not want to oppose India for this purpose. Russia has always been pro-India because during cold war India always Supported Russia and also maintained relations with America. China is the only country who has always Supported Pakistan at all occasions. China has a strong partnership with Pakistan to reduce the brutality of Indian military.

Unfortunately, SAARC Countries have not shown any kind of support to UN Charter regarding this issue. Even OIC countries are more interested to start trade with India instead of helping Kashmiris. Muslim countries are not showing the Unity for this cause only a few countries are showing strength with Pakistan. These are Saudi Arabia, Iran, Turkey and Yemen and now Malaysian President also supported Pakistan in resolving this dispute.

Russia is the main ally of India who supports India by Supplying defense hardware and Tashkent agreement is part of that Support. Russia is now developing trade ties with Japan, China, European Union and even with Iran. Now Russia wants to influence central Asian States with the economy and military power.

Although Pakistan has always been strong Ally of United States and fought an American war in Afghanistan but in spite of all these favors done for US, United State is not doing any favor for Pakistan rather focusing on their economic Superiority over other countries of the world.

Central Asian countries are not united neither they are behaving like Ummah so it is difficult to expect any support from them. They are also focusing on their economic ties with India. Pakistani Prime Minister said now we are alone fighting for Kashmir but one day other countries will stand with us, we are hopeful.

\subsection{Role of United Nation To Settle Kashmir Issue}

United Nations is a strong international organization to maintain peace in the world and to settle down conflicts among countries. The General 
Assembly and Security Council are two main responsible organizations working on Settling down disputes around the world. As it is mentioned earlier that the Security Council has the right to call on both. The UN also has the option to call upon the peacekeeping missions to do more. In spite of many challenges UN is trying to solve this tension between India and Pakistan. (Shamsuddin, M.N, 2014, p. 25).

Even in 1998, Secretary general Kofi Anan of that tenure included Kashmir with other hot issues around the world like Cyprus \& civil war in Sudan, ethnic violence in Kosovo and unrest in Congo.

The UN has the right to exercise its power and ensure peace in Kashmir and should have plebiscite. It can arrange talks between the two countries facing problem. If UN exercises its right, it can support both Countries resolving the conflict and saving the people of Kashmir. When we talk about Plebiscite it is according to UN Resolution of January 1949 which laid down. "The question of the accession of the State of Jammu and Kashmir to India or Pakistan will be decided through impartial plebiscite under United Nations" (Ministry of Foreign Affairs, 1949, January 10).

India is trying to capture the whole area, if it is accepted, it would be a great problem for Pakistan that will weaken its economic and military powers. At present India needs to reduce tension at the LOC. It is desired by UN to send its military forces to the conflict area to maintain peace.

\section{METHODOLOGY}

Qualitative research method has been used to explain the background of the Kashmir issue and the role of United Nations. The Kashmir dispute is as old as the two states themselves that is India and Pakistan, dating back to their independence from the Britain and partition of sub-continent in 1947. The Kashmir conflict had become a great threat to south Asia's peace and to the global security in the $21^{\text {st }}$ century. While explaining this issue, data was collected from different books, written on this topic, for example 
1. Kashmir, roots of conflict path to peace by Sumantra bose

2. The origin of war in south Asia the Indo-Pak conflicts since 1947 by Sumit ganguly.

3. Different articles on Kashmir by AJK President Sardar Masood Ahmed Khan

Apart from these books, data was analyzed through some records of previous researchers, newspapers, articles and reports. Although this topic has been discussed several times, so providing additional evidence and analyzing its validity on the basis of different sources is very important. The article was prepared to analyze the social reality of Kashmir issue and the people who are living there and facing problems while UNO is claiming its existence as a problem saving organization. Pakistan is doing its best to resolve this condition but Pakistan cannot go beyond extending moral, political and diplomatic support to the cause of Kashmir.

\section{RESULT}

Kashmir is a conflict area between Pakistan and India and in spite of many efforts conflict is not being resolved. The aim of this research article was to highlight the real issue of Kashmir and to take concrete steps towards the resolution of this dispute with the help of UN resolution.

Pakistan and India both are nuclear powers so no military solution to Kashmir dispute is possible (Khan, 2020, July 13). That's why Pakistan wants UN to follow international law to resolve this issue. UN can hold a plebiscite in Kashmir to become aware of their wishes, that is, which country they want to join either Pakistan or India.

The principle of self-determination is generally considered paramount when it comes to territorial dispute. Although it is not so simple. Pakistan is trying to resolve this conflict diplomatically at all forums to improve its relations with its neighbor, so that the dispute can be resolved smoothly. United Nation did not implemented international law to resolve Kashmir issue that's why the role of diplomacy appears to be a failure.

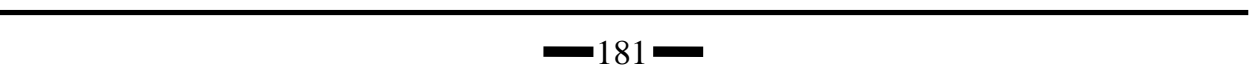




\section{DISCUSSION}

The article is about the importance of diplomacy on part of UNO in case of Kashmir dispute the conflict area between Pakistan and India since the independence of Pakistan from British India.

The dispute started in 1947 over the state of Jammu and Kashmir and surge into three wars.

Kashmir has three sub regions

1. Jammu

2. Kashmir

3. Ladakh

This whole area comprises of people who are culturally, religiously and ethnically diverse. Hindus are living in Jammu, Buddhist lives in ladakh and Muslims in Kashmir valley. Muslims are pre dominant in Kashmir valley, however both in Jammu and ladakh Hindus and Buddhist are dominant. Many Muslims would like to join Pakistan but non-Muslims would like to join India. The Muslim part is in between the Hindu part and Buddhist part which means cutting away the Muslim part and merging with Pakistan is not easy. The Indian claim that Jammu and Kashmir are its integral part on the basis that the Hindu maharaja had signed the instrument of excision to India. This claim had always been doubtful because actual decision had to be subjected to a plebiscite. India further claims that after Shimla agreement Kashmir is a dead issue because this agreement set aside the decision of united nations security council. This is against the laws of UN because both countries had not approached UNSC to amend the old ruling which remains valid. The Indian leaders are aware of the fact that the majority of Kashmiri population wants to get out of Indian dominance. Kashmiris have been fighting with Indian forces since 1948 and are sacrificing their lives while India is suppressing the emotions and outraging the common civilians by force. It has not worked till now and will never work. Indians must understand the democracy they enjoy is not the same for the people of Kashmir. According to Majid \& Hussain (2016), the issue faced by Kashmiris tells us that the Indian security forces 
in Kashmir deployed 150,000 para military forces with police personals that violated the human rights of the locals.

\section{CONCLUSION}

This research has explored the success \& failure of diplomacy on part of United Nation Organization and international community in case of Kashmir issue. On many occasions Pakistan has raised its voice many times at international forum to end violence in Kashmir and to utilize the right of self-determination of Kashmiris through a promised UN sponsored plebiscite.

Since 1948 different explanations and implementations has been suggested to resolve the issue of Kashmir. Former Prime minister of Pakistan Feroz khan noon and former President of Pakistan Ayyub Khan recommended all possible solutions including impartial plebiscite in Kashmir. In 2006 former president of Pakistan general Pervez Musharraf suggested four points formula.

Pakistani President Ayyub Khan suggested alternatives to plebiscite. Ex Pakistani Prime minister Z.A.Bhutto and Ex Indian cabinet minister Swaran Singh held a meeting regarding the solution of Kashmir. In 2006 general Musharraf who believed both Pakistan and India would have to retreat from positions held since 1948 came up with four point's formula.

1. It includes de-militarization and self-governance with join supervision mechanism.

2. Kashmiris should be allowed to move freely on both sides of Line of control.

3. Kashmiris should be given self-governance right and both countries should withdraw their troops from the region.

4. There must be a plan for Kashmiri people so that they could follow that accordingly.

General Musharraf said this plan will work from 7 to 15 years and after this given time people of Kashmir should be asked about this plan, if they 
agree with it then it should remain permanent and if they don't agree then another mechanism should be applied according to their wishes.

Professor Abdul Ghani Bhatt a former chairman of the hurriyat conference in Kashmir valley. Respond to these four points formula as acceptable one. He said no country will face defeat and problems will be solved smoothly. According to the findings, diplomacy is the only way towards success because all the parameters involved in avoiding failure can only be achieved if diplomacy is taken into consideration and it will eventually end all the violence and issues that have been faced by the governments in the past. 


\section{REFERENCES}

Barston, R.P. (2014). Modern Diplomacy. London: Routledge.

Biswas, A.K. (1992). Indus Water Treaty: The Negotiating Process. Water International 17(4), 201-209.

Blair, T. (2010). A Journey: My Political life: New York: Vintage Books. 699.

Cohen, S. P. (2004). India: Emerging Power. Washington: Brookings Institution Press.

Dar, U.K. (2017, May 27). A Sustainable Solution for Kashmir. Pakistan Today. https://www.pakistantoday.com.pk/2017/05/27/a-sustainablesolution-for-kashmir/

Faizullaey, A. (2006). Diplomacy and self. Diplomacy and Statecraft, $17(3), 497-522$.

Gazit, M. (2013). Israeli Diplomacy and The Quest For Peace. London: Routledge.

Harpher, K. (1994). Does the United Nations Security Council have the competence to act as court and legislature. NYU Journal International Law \& Politics. 27.103.

Hinnebusch, R., \& Zartman, I. W. (2016). UN Mediation in the Syrian crisis: from Kofi Annan to Lakhdar Brahimi. Raymond Hinnebusch, I. William Zartman, et al., "UN Mediation in the Syrian Crisis: From Kofi Annan to Lakhdar Brahimi," New York: International Peace Institute.

Jackson, W.D. (1998). Soviet Reassessment of Ronald Regan, 1985-1988. Political Science Quarterly. 113(4), 617-619. 
Kapur, S.P. (2008). Ten Years of Instability In a Nuclear South Asia. International Security 33.(2). 71-94.

Khan, S. M. A. (2020, July 13). AJK President Vows to Carry Mission of Kashmir Martyr by: The Nation. https://nation.com.pk/13-Jul2020/ajk-president-vows-to-carry-forward-mission-of-kashmirmartyrs.

Kissinger, H. (2012). Diplomacy. London: Simon \& Schuster, Limited, $114-115$

Majid, A. \& Hussain, M. (2016). Kashmir: A Conflict between India and Pakistan. A Research Journal of South Asian Studies, 31(1). 49 - 159

Ministry of Foreign Affairs (1949, January 10). Resolution adopted at the meeting of the United Nations Commission for India and Pakistan on $5 \quad$ January, $1949 . \quad$ http://mofa.gov.pk/wpcontent/uploads/2020/01/Resolution-adopted-at-the-meeting-of-theUnited-Nations-Commission-for-India-and-Pakistan-on-5-January1949.pdf.

Mohan, A. (1992). The Historical Roots of the Kashmir Conflict. Studies in Conflict \& Terrorism, 15(4). 283-308.

Niksch, L.A. (2010). North Korea's Nuclear Weapons Development and Diplomacy. Washington, D.C. : Library of Congress, Congressional Research Service.

Nixon, R. (1998). American Foreign Policy: The Bush agenda. Foreign Affairs 68(1), 199-219.

Schofield, V. (2010). Kashmir In Conflict: India, Pakistan And the Unending War. London: Bloomsbury Publishing.

Schrijver, N. J. (2006). The Future of the Charter of the United Nations. Max Planck Yearbook of United Nations Law Online, 10(1), xxiii-34. 
Shamsuddin, M.N, (2014). The Role of the United Nations in the Kashmir Conflict: An Analysis. The Journal of Defense and Security, 5(1), 25.

Soetendorp, B. (2002). The EU's Involvement in the Israeli-Palestinian peace process: The building of a visible international identity. European Foreign Affairs Review, 7. 283-295.

Telhami, S. (1990). Power and Leadership in International Bargaining: The Path to the Camp David Accords. Columbia: Columbia University Press.

Vanhoonacker, S., \& Pomorska, K. (2013). The European External Action Service and agenda-setting in European foreign policy. Journal of European Public Policy, 20(9), 1316-1331.

Viotti, P. R., \& Kauppi, M. V. (2013). International Relations and World Politics. Boston, MA: Pearson.

Watson, A. (2013). Diplomacy: The Dialogue Between States. London: Routledge. 